\title{
Aesthetics of Symbolism and Semiotics in Afghan Cinema
}

\author{
Abbas mohammadi \\ Avicenna University, Afghanistan
}

\begin{abstract}
Symbols and symbols are two important semantic criteria in the aesthetics of cinema. Semiotics studies the production and presentation of meaning and concept in any work of art. By sending codes and symbols, the sign tries to express other meanings in the interpretive language other than its apparent meaning. Therefore, art that is mixed with the language of symbols and signs has very deep cultural and traditional meanings and concepts of that border and environment. To get the meaning of the image, we must have a complete and accurate knowledge of the language of symbols and signs. Symbols and symbols are widely used in movies and television all over the world. Also, in many films produced in Afghanistan, many signs and symbols have been used but not the symbols and signs that are used all over the world Rather, traditional cultural and traditional symbols have been used in Afghanistan. This was quite different in post-war films, especially in the post-Taliban era in Afghanistan. Throughout the history of Afghan cinema, Afghan cinematographers have never tried to address the origins of signs. Rather, they were content with a generalization of symbols and signs. One of the uses of symbols and signs is to create suspense in drama and storytelling. But Afghan filmmakers could not use symbols and signs to create suspense for their audience. This led to the failure of many films and filmmakers to use symbols and signs in Afghan cinema and caused to lose their internal and external audience. But in recent years, new and young filmmakers have entered the world of Afghan cinema in this field, they were able to make good use of symbols and signs and engage the minds of their audience with symbolism and semiotics. And convey the specific message of the film to them through symbols and signs.
\end{abstract}

Keywords: Aesthetics, Symbolism, Semiotics, Cinema, Afghanistan.

\section{Introduction}

What we use today as a symbol in the universe is nothing which has been created in the last few years, but also has a long-standing symbol and sign. Many of the symbols and signs are several thousand years old, and some of them may be considered in line with the creation of humanity. And maybe more to read. A symbol is something that is used in human society for different purposes in different situations. A symbol is essentially something which leads us to a meaning beyond what we are seeing. Using symbols and signs in the visual arts section is to achieve a new view of the viewer. To achieve concepts of superiority through it. When the audience can get countless meanings from a work of art, they can access the theme of that work of art. It is at this point that we can say that man has reached an aesthetic or aesthetic. Aesthetics is nothing separate from philosophy because the job of philosophy is to interpret. Therefore, until we can interpret the nature of a work of art, we will not reach its existential principle and as a result, we cannot achieve its aesthetics and aesthetics. Symbols and symbols are exposed to philosophical interpretation with the concepts they contain and they create a new meaning. These meanings have been different in different times and in different circumstances. Because "from ancient times to the present day, most of the topics related to art, It has been about the relationship between man as an artist and nature as the subject of the artist's work. An activity we call art is a technical process by which we draw or represent something - what? The simplest answer is that the artist draws the outside world and what he sees with his eyes. If this is the only goal of the artist, then he has seen nature in very different ways in different historical periods "(Reed, 93, 2008).

This is shown by Herbert Reid That we cannot look at two works of art from one angle because that round of the work may have been created in two different periods. At the same time, their formation can differentiate them from each other and as a result, the perception of the two will be completely different and in principle we can say the aesthetics of a work of art to the time and place and conditions of the artist who created it has a direct relationship in the sense it presents to the audience.

\section{The cinema}

In the early days of cinema, only a few moving images were silent Which was placed next to each other to entertain the spectator or make him laugh. But over time, sound entered the cinema and it can be said that the entry of sound into the cinema was a great revolution in this industry. As a result, the number of cinemas increased day by day. It did not take long for cinema to take its place all over the world. Following that, different styles, forms and structures entered the world of cinema industry one after another by filmmakers. And this magical art of the 21 st century became a tool for artists and filmmakers around the world to use it to present their desires, thoughts and ideologies directly and indirectly to their intended audience.

When the cinema can communicate with the audience and speak to them in the language of images In this case, the cinema can no longer be just a moving image. Rather, the filmmaker with the arrangements and techniques at his disposal, unlike the stage and theater, he can take control of the audience with his creative mind and to convey what he has in his 
imagination to his audience with the language of art and image and in the form of cinema art And transform his inner world as he wishes and create a new world for him, thus taking away his decision-making power. And he decides for himself and slowly leads the audience to where he is aiming. Cinema needed the help of other arts to be able to achieve such a power of audience control. In order for cinema to achieve its goal, it used all the other arts, The same use of other arts such as light, color, mezzanine, music, decor, architecture, dance, song, etc. was observed to enter the cinema as a symbol and sign. And open a new world of meaning and concept for its audience.

\section{Symbolism and semiotics}

When we enter the world of art, especially the art of image and cinema, we first enter into the discussion of meaning and concept. Meaning and concept without symbols and signs may not have complete meaning. Therefore, we must first know the meaning of the symbol and the sign. A symbol is basically something that resembles something or evokes something else or it represents something else under a pre-determined contract and in most cases it is a material and visible object which refers to a phenomenon other than itself, such as the bird cage, which has both its meaning and the meaning of prison.

The sign is slightly different semantically from the symbol. Anything that represents anything other than itself is called a sign. In essence, a sign is something that cannot have the same meaning Signs are always multifaceted and mean several meanings at the same time. But it should not be forgotten that sometimes the sign has several meanings at the same time this issue itself is divided into obvious signs and hidden signs in such a way that if the sign is used and used, it will have the same meaning as it is intended In such a case, the sign has an obvious meaning But if the sign indicates something other than its original and real meaning, in such a case the sign has a hidden meaning. Which must be interpreted semantically and the hidden meaning of the sign is revealed. "This question arises when the sign is organized as a science Does this science really include expressions based on perfectly natural cues such as dumb play? Assuming this new science adopts such practices, the main focus will continue on all groups of systems based on the optionality of the sign. In fact, all the means of expression used in society are basically based on collective behavior, or in other words, on the basis of contract. In general, etiquette, although often full of a kind of natural rhetoric (As in the case of a Chinese man who pays homage to his emperor by bowing to the ground nine times), However, they are based on rules. These are the rules that oblige one to apply them and not the intrinsic value of movements. Signs that are at their disposal, better than other signs, they ideally visualize the semiotic process. That is why language is the most complex and general system of expression, as well as the most characteristic of them. In this sense, linguistics can be a comprehensive model for all branches of semiotics.
However, language is only one of the semiotic systems" (Woolen, 122, 123, 2013).

Woolen tries to introduce us to an expressive grammar because when a grammar was made for something at that time, everything can be put in the form of grammar and received the desired concept from it. This can only happen if we use the tokens as needed. But signs are essentially non-verbal systems. "It is only in very rare cases that non-verbal systems can exist without the support of verbal ciphers. Even hard-to-develop systems such as painting and music are constantly resorting to weapons. Especially on a popular level. Songs, comics, and posters. In fact, one can even write a history for a painting based on the changing ratio between words and pictures. One of the main achievements of the Renaissance was the exclusion of words from the image space. "(Woolen, 123, 124, 2013).

The words of Peter woolen show that symbols and signs had no place for themselves until they distanced themselves from the system and the theological world. When they separated from the theological system and the theological system became the visual system, they had wider meanings. Therefore, by establishing a visual system, cinema was able to create a verbal and linguistic position for itself. Because cinema is a visual and dynamic art that speaks to images. Art that has a language that is specific to cinema is something that Christine Metz also emphasizes. Metz believes that any system in an existing situation must have rules and be based on the rules of that system. According to Christian Metz, cinema itself has a language, and that language is subject to a rule this makes each filmmaker make a film in a specific style and structure. In cinema, the filmmaker speaks the language of images but for each filmmaker, there is a specific type of grammar that he uses in his film According to Christine Metz, this is the grammar of a film for a filmmaker that he makes for himself.

When a language is spoken, a contract is made between the sender and the receiver to send and receive the code, which are the symbols. But what is important here is that in the first step we must understand the meaning of the symbol and the sign. Semiotics is essentially a science that must be learned Peter Woolen describes semiotics in his book Signs and Meaning: "One can imagine a science that examines the life of signs in society. This science will be part of social psychology and therefore part of general psychology. This science shows what is the nature of the symptoms? And what laws govern them? And since it does not yet exist, no one can say what it will be. But it has the right to exist and a predetermined place. Linguistics is only part of the science of semiotics. The laws that semiotics will discover can be applied to linguistics as well." (woolen, 121, 122, 2013).

According to Peter Woolen, we cannot separate semiotics from linguistics because semiotics itself is part of language and language is part of semiotics, both of which are part of psychology Thus, semiotics, linguistics, and psychology are three categories Which are inseparable from each other In essence, 
these three, by being together and influencing each other, create a form of meaning and concept. In the world of cinema, they form a new language called film language and visual language. This is essentially the same image as the sign As Jean Mitry states in his book Psychology and Aesthetics of Cinema, Jean Mitry says: "In every film, every image - even if it is at least well defined It has the capacity to already have a definite meaning, Even before this image is combined with another image to create a meaningful meaning. All people, events and all things have a special meaning because of their presence in the world. It is natural for the image to present these to our eyes that the initial meaning of the image is derived from the same issues that they present "(Mitry, 58, 2015).

Jean Mitry is basically trying to make us understand in the science of existence we have two meanings, one is the original meaning of everything that lies in its essence and it can be received and understood by anyone. The second meaning is related to the combination of things that come together in the universe or a person puts them together and tries to get a new meaning from them. Jean Mitry reminds us that when watching a work of art we must first understand the intrinsic meaning of that work and its composition then look for another meaning in which the work lies. But it can be said that there may be a third meaning in that work of art. That third meaning is obtained by combining the original meaning and the meaning obtained by combining the first meaning with the second meaning, which is the third meaning. It is in this state that semantic philosophy emerges and in essence, the ultimate goal of the association of symbols and signs is to create a third meaning in a work of art. In the universe we cannot separate or ignore symbols and signs. Because symbols and signs provide us with a way to better understand the meaning of objects. In today's world, everything is mixed with symbols and signs. Today's world cinema is meaningless without symbols and signs. Because, as Peter woolen said, signs have taken the place of words, and filmmakers no longer speak with words. Rather, they try to convey their message to their audience with a symbol and symbol in the form of an image, which is the language of cinema. Because one of the definitions of language is a set of signs and codes that cause communication between human beings. By this definition, we are convinced that the image is also a language because it has a set of visual cues that cause communication.

The image always has a message and news for the audience. "A visual news can have meaning in two ways, one way is the special meaning that is in the symbols or codes and through our shared experiences of the environment, which evoke the meanings of a visual story." The difference in visual perception among audiences stems from these two factors. Consider, for example, a traffic light at a crossroads a red light all over the world for a car driver means a stop order, a symbol of contract throughout the world, but a tree or a desert will have different effects depending on the experience of different people with different biological geographies (Dondis, 48, 2014).

\section{World Cinema}

In today's world, cinema has become an ubiquitous tool. In the 21st century, there are few countries without cinema and film production. Cinema is an intellectual tool by which the creator of a cinematic work challenges the mind of its audience intellectually and spiritually. Cinema film analysis, due to its breadth, is one of the thematic duties in various fields of humanities. From the time of the advent of cinema, for a long time, the method of analyzing this art of cinema was an aesthetic look at film. But today, the method of film analysis has taken a different form. This change from an absolute aesthetic point of view to a combined analytical point of view, Such as semiotics and narrative analysis, the result of the efforts of thinkers in various fields of sociology, researchers in the field of anthropology, Critics of literature, cult urologists, linguists, etc. Today's cinema critics come up with a new concept by considering all these things and connecting them with symbolism and semiotics. Almost today we have come to the conclusion that semiotics is an important part of the art of cinema. Few filmmakers, critics, filmmakers and theatrics can be found who are not involved. Some signs, because of the great similarity with the subject and others because of the unity of meaning between the signs and the subject under consideration and some other signs according to the type of different societies and social contracts that have been made In the form of symbol function, they are categorized between signs and subject in different sections.

But in the case of a critique of a cinematic work that is inherently visual, it means that the five human senses are involved with it. There have been disagreements among theorists over the relationship between the signs and the subject matter of the film, which have so far failed. And the kind of critique that is made of a film is the kind of critical view of the relationship between subject matter and signs. In order to better understand semiotics in cinema, let us give an example. Consider a movie that is speechless and silent, you see the movie. When you see scenes and characters in a movie, sometimes you laugh and sometimes you get sad and sometimes you get excited. It is in this state that the signs such as the environment, the type of film directing technique, the movements of the actors, the costume design, etc., all speak to you in the form of a film. In fact, watching a movie, looking at a painting, listening to a piece of music, etc. may mean talking to someone. That work of art is his spoken language, a language that is not a human language but a language. For example, when you watch the documentary "Baraka" by Ron Frick, you are faced with images that may not make sense alone. But when images with elements of different religions are placed next to each other. In essence, the language of cinema (the language of images) expressed by sign language may not be an official language and does not have a formal language structure that can be considered as a language system. Simply put, it does not have a single structure, let's call it a single language. In such a situation, the person who reviews the film uses the 
tools of signs to critique the film based on what he has learned, feelings, information, culture, traditions, and so on. Each critic decodes the symbols and signs based on his own mental resources and provides them to his audience.

Semiotics and symbolism have entered this art since the early days of cinema. The best symbolism of color is portrayed by Polish director Christophe Kieslowski. $\mathrm{He}$ is in the beautiful and enduring film Blue, produced in 1993, which is a symbol of faith, patience, peace and self-sacrifice. Used correctly. To be able to convey his message to the audience. Eisenstein, the director and one of the greatest montage theorists in Russian cinema, has used symbolism and signs in many of his works. Showing sculptures, climbing stairs, long shadows, etc. made his films have a more meaningful theme. Also Orson Welles in "Citizen Kane", with a very beautiful mezzanine and a lot of depth of field to discover the secret of the rose And looking for a reporter in Mr. Kane's private life as beautifully as possible It uses symbolism using light, scene design, depth of field, camcorder movements, measured framing, and appropriate composition. For example, in the sequence where the lawyer comes to win Kane In one scene, the camera pulls back slightly and shows the child on the snow outside the room That shrinks, and in the new frame we see Kane's godfather, lawyer, and mother talking about Kane. And they decide on his future. In the beginning of this scene, Orson Welles, with a proper framing, puts Kane in the center of his picture frame and shows him playing with his sled. The sledge that Mons is a child alone and taken from him when he goes to the city with all his desire is here. The sledge is essentially a symbol of Kane's lost innocence.

Asghar Farhadi, an Asian director, also uses symbols and signs in his films. Farhadi starts the film with a false theme in the film about Eli, which is originally a travelogue film. In this film, travel is a symbol of self-knowledge and introversion, because in travel, human beings reveal their inner relationships. The film begins in the dark. Sounds that are heard but nothing is seen. The film begins in the dark. Sounds that are heard but nothing is seen. From inside, the darkness of the image opens and light is seen. And the characters come out of the tunnel. The tunnel is basically a symbol of the interior of these characters that is going to open. A villa in the north, with broken windows, symbolizes the insecure and broken atmosphere between the characters in the film. People who lie to each other and do not know each other completely.

Majid Majidi is another director from Iran who tries to use symbols and signs in some of his films. In the movie "Rain", Majidi tries to portray the transformation of a human being through love Majidi uses a bakery oven to show this transformation. Shows the character that is going to change in the movie in the bakery. Because the dough changes when it is exposed to fire, and then it becomes something that no longer has that first kind. Latif, the character of Baran movie also changes after being confronted with the love of Baran and it is no longer the first Latif. What was very valuable to him at first is now worthless, and what was worthless is now valuable. In this film, Majidi takes dough and bread as a symbol of man and human insides. When man is exposed to problems and struggles with them, in the end he becomes a new person who has achieved a new ideal, which is much more valuable than the first thing. In the movie "Crazy Willow", Majidi tries to portray social symbols within a man's life in two social classes. But in the movie "Song of Sparrows" he distances himself from the superficiality of symbols and finds a more artistic payoff and is in-depth in the current situation, the metaphors that were present in Majidi's popular works go deep into the subject without disturbing the storyline of the real film. The ostrich in the film is one of the concepts in his film that apart from its realistic function, it can take on the meaning of human nature for an audience that seeks meaning and concept. When the man loses the ostrich, he goes in a very beautiful sequence to find it in the ostrich skin to find his lost one. The type of shot that Majidi has chosen for this scene has helped a lot to symbolize that movement the audience understands that sometimes you have to be different to get what you are looking for. In this shot, Majidi portrays people who are not really themselves and they try to be in any way to achieve their ultimate goal so that they can fulfill their desires. In this scene, Majidi has taken this character movement as a symbol of hypocritical people who look like everyone but are completely different inside them.

In Afghanistan, as in many other countries, since the advent of cinema in Afghanistan the filmmakers sought to influence the audience Therefore, they tried to convey their message to the audience by storytelling and using symbols and signs. Directors like Saeed Orakzay try to portray the story of the Afghan people using traditional symbols and symbols within the culture with the film "Men Promise" Which has been very successful in this work. Orakzay uses a kite in his film. A device that is commonly used in Afghanistan for the New Year and for fun and entertainment. The movie character uses it to convey his congratulatory message to his mistress. Another filmmaker who has used symbols and signs very well and accurately in his film is Afghan director Atiq Rahimi, who currently lives in France. Atiq Rahimi is making his first film after the Taliban rule based on a story of his own. The script is written by Composia Partovi, one of the Iranian cinematographers. Symbolism is also prominent in "Ash and Soil." One of the symbols that is well used in this film is the deafness of Yassin, the grandson of Dastgir Khan. A young child speaks for himself, but hears no sound. The filmmaker takes the child as a symbol of all the children and youth of Afghanistan. A generation that is afraid of war. Elsewhere, a sheep goes to the mine and explodes, and Yassin throws himself into his grandfather's arms in fear. Here, the sheep is essentially a symbol of Afghanistan's wealth, which is being destroyed by war and that explosion takes joy and happiness from the child. Here, in the essence of this war, it takes joy and happiness from the people of this land. Atiq Rahimi in the film "Ash and Soil" shows the war from its destructive aspect and it tries to show that war has one dimension of material 
destruction and the other dimension of its destruction occurs among human beings. It is seen among friends and acquaintances and in family relationships, and especially father-son relationships. Although war in a country like Afghanistan is generally discussed ideologically, politically and religiously But Atiq Rahimi wants to raise the issue of war in terms of human relations and examines its inevitable compensatory effects on these relations and even relations between relatives. In another part of the film, Rahimi portrays a woman with a daughter under a tang left over from the war. Symbolically, it can be said that the woman is a symbol of the homeland that has survived a long war in this country. Or the bride of Dastgir Khan, who is also a mother and gets naked in the war and runs back and forth helplessly and wandering so that she can find shelter. This could be a symbol of Afghanistan, which has been wandering in this war for many years. Atiq Rahimi has used a lot of symbols and signs in his second film "Sang Sabour". The Patient Stone depicts the life of a woman who hopes for a man who cannot even shake herself. Atiq Rahimi in this film also takes the woman as a motherland, a homeland that is attached to those who cannot even protect themselves. Rahimi also uses symbols and signs in different parts of the film and tries to use them to convey his message to the audience. In another part of Atiq Rahimi's film "Patient Stone", he uses a knife, a tool that is sacred in many places. And in many places it can be catastrophic. In part of the film, when a stranger enters a woman's house, a knife is a weapon for her to defend but when her husband comes out of unconsciousness with her words and regains consciousness And grabs the woman by the neck to kill her. The same stone knife kills her patiently. Here, in both cases, the knife was a lifeline for the woman, once from a stranger and once from her husband. But it should not be forgotten that salvation in these two situations is quite different. The knife is used as a sacred tool in one place and vice versa in another.

After the wisdom of the Taliban in Afghanistan, it was not only men who made films, but also male and female filmmakers. Sahra Karimi has tried to portray a part of the life of Afghan women in her film by making the film "Eve, Maryam, Aisha". Sahra Karimi portrays three women in her film all three are pregnant and bring someone into this world that is itself a victim of this patriarchal world. At the beginning of the film we see Eve and her father-in-law, and the bird in the old man's cage, a cat nearby, at night we see rat traps that the old man has spread on the ground to catch a cat. The dove and the Quran are the symbols we see in the first minutes of this film. An old man who traps a cat all over the floor to catch a cat. But on the night Eve's husband invites a guest home, but in the dark, Eve gets trapped instead of a cat and falls to the ground. This accident caused the baby to be injured in her womb. In this film, Karimi shows that there are hundreds of problems and troubles in the lives of people like Eve that she has to deal with. And find her way of life among them and move on. In another scene, we see Eve feeding the mouth of her stroke-stricken mother-in-law. It is one of the most beautiful and meaningful scenes in the movie. Close-up of an old woman who is silent and cannot speak every time Eve puts food in her mouth The old woman gives Eve a deep and meaningful look. These meaningful glances of the old woman represent the destiny that is shared between Eve and her. The old woman's gaze reflects her concern that she sees herself as the future of Eve.

In Eve, Mary, and Aisha, we are confronted with a system of spoken signs. In the film, the female voice is the dominant voice of the film. Men's voices are less heard in the life of Maryam and Aisha, we do not see men throughout the film, the voice that is heard most often speaks to the audience and sends a message to her that the voice of a woman is a woman who is hurt by men. Sahra Karimi consciously removes the voices of men in order to put women in a decisive decision. Karimi, on the other hand, emphasizes the woman alone in her film, putting her in a position where she has to fight to survive. This grueling struggle appears at the end of the film. Where we see all three women (Eve, Mary, Aisha) To get rid of all the hardships and troubles, they have come to steal the child inside. When we look at the place of Eve, Mary, Aisha, we can see traces of Italian neorealist films and the structure of Ingmar Bergman's films.

Roya Sadat is another filmmaker who has made films in Afghanistan in recent years and has used the characters well in her film. Roya Sadat made a name for herself with the film "Letter to the President". Roya Sadat, like Sahra Karimi, addresses the problems of Afghan women. But the woman in Roya Sadat is not the woman of Sahra Karimi. The film "Letter to the President" depicts the life of a woman who has a relatively good position in society. The film "Letter to the President" depicts the life of a woman who has a relatively good position in society. The woman in Roya Sadat is not as calm and obedient as other women in Afghan films. She is a rebellious and rebellious woman. The woman in Roya Sadat is a symbol of the modern and modern women who are fighting for their rights. We see symbols and signs everywhere in Roya Sadat, but the best scene and in fact the strongest scene in "Letter to the President" is the scene. The woman is on the stairs to climb between her father-in-law, who is traditional, and her husband, who is somewhat modern. After an argument, the husband slaps the woman in the face and prevents her from climbing. The woman who finds herself between the two is not silent and slaps her husband and opens her way and goes upstairs. This scene shows the courage of today's Afghan women who fight against problems and obstacles instead of retreating and opening their way to ways and progress. In recent years, many filmmakers have entered the field of filmmaking in Afghan cinema who have new ideas. And the films they have produced have been able to enter world festivals and gain a place for themselves. 


\section{Result}

Cinema, with all its ups and downs, has found its way to evolution towards hegemony. Today, filmmakers around the world no longer seek to entertain audiences rather, they try to convey their specific message to a specific and general audience through cinema. Of course, this audience is not only on the border of their own web, but also cinematographers think of foreign audiences to reach their voice to the four corners of the world through cinema. Filmmakers are no longer looking for realistic images like in silent cinema, but they are trying to create meaning by using symbols and signs in images. Since the advent of cinema, Afghan filmmakers have sought to transform their society through cinema. Cinema after the Taliban regime is completely different from cinema before it. Afghan filmmakers in the cinema they formed after the Taliban rule in Afghanistan They tried to use more symbols and signs in their films so that they could make their voice heard and that of Afghan society to their global audience. During this period, many filmmakers from inside and outside Afghanistan produced films with the themes of Afghan society in a new style and structure and presented them to the international community.

\section{Resources:}

Reed, Herbert. (2008). Philosophy of Contemporary Art, translated by Faramarzi, Mohammad Taghi, third edition, Tehran, Negah.

Metz, Christine. (2016). Semiotics of cinema, translated by Safarian, Robert, Tehran, Basirat.

Wollen, Peter. (2013). Signs and meaning in cinema, translation: Tarbiat, Abdullah, Taheri, Bahman, sixth edition, Tehran, Soroush.

Mitri, Jean. (2015). Psychology and Aesthetics of Cinema, Translation: Azimi, Shapoor, Second Edition, Tehran, Mehr.

Dandis, Donis A. (2014). Principles of Visual Literacy, Translation: Sepehr, Massoud, 40th Edition, Tehran, Soroush.

\section{Filmography:}

Baraka. (1922). Directed by Ron Frick, USA.

Citizen Kane. (1941). Directed by Orson Welles, USA.

About Eli. (1999). Directed by Asghar Farhadi, Iran.

Rain. (2000). Directed by Majid Majidi, Iran.

Crazy Willow. (2004). Directed by Majid Majidi, Iran. Iran.

Song of the Sparrows. (2000). Directed by Majid Majidi,

Ash and dirt. (2004). Directed by Atiq Rahimi, Afghanistan.

Patient stone. (2012). Directed by Atiq Rahimi, Afghanistan.

Eve, Mary, Aisha. (2019). Directed by Sahra Karimi, Afghanistan.

Letter to the President. (2017). Directed by Roya Sadat, Afghanistan. 